\title{
GMR
}

\section{Polymorphism E23K (rs5219) in the KCNJ11 gene in Euro-Brazilian subjects with type 1 and 2 diabetes}

S.W. Souza ${ }^{1}$, L.P. Alcazar ${ }^{1}$, P.A. Arakaki ${ }^{1}$, I.C.R. Santos-Weiss ${ }^{2}$, D. Alberton ${ }^{1}$, G. Picheth ${ }^{1}$ and F.G.M. Rego ${ }^{1}$

${ }^{1}$ Programa de Pós-Graduação em Ciências Farmacêuticas, Universidade Federal do Paraná, Curitiba, PR, Brasil

${ }^{2}$ Departamento de Patologia Médica, Universidade Federal do Paraná, Curitiba, PR, Brasil

Corresponding author: F.G.M. Rego

E-mail: rego@ufpr.br/fgmrego@gmail.com

Genet. Mol. Res. 16 (2): gmr16029543

Received November 18, 2016

Accepted February 17, 2017

Published April 5, 2017

DOI http://dx.doi.org/10.4238/gmr16029543

Copyright (C) 2017 The Authors. This is an open-access article distributed under the terms of the Creative Commons Attribution ShareAlike (CC BY-SA) 4.0 License.

\begin{abstract}
Insulin secretion is regulated by ATP-sensitive potassium channels (KATP). The potassium inwardly-rectifying channel, subfamily $\mathrm{J}$, member 11 (KCNJ11) gene, located on chromosome 11p15.1, encodes the subunit Kir6.2 that forms the pore region of KATP channels in pancreatic $\beta$-cells. Among the single nucleotide polymorphisms (SNPs) associated with KCNJ11, the E23K polymorphism (rs5219) promotes a substitution $(\mathrm{G}>\mathrm{A})$ of a glutamic acid residue for lysine at position 23. The E23K SNP has been associated with diabetes in several populations, although with controversial results. The aim of this study was to evaluate the association of the E23K SNP with type 1 and 2 diabetes in a case-control study approved by the Ethics Committee. We genotyped 458 Euro-Brazilian individuals, classified as healthy (control group, CTRL, $\mathrm{N}=217$ ), patients with type 1 diabetes mellitus (T1D, $\mathrm{N}=102)$, and patients with type 2 diabetes mellitus
\end{abstract}


(T2D, $N=139$ ). Genotyping was performed by polymerase chain reaction-restriction fragment length polymorphism (PCR-RFLP) using BanII restriction digestion. The restriction fragments were separated by polyacrylamide gel electrophoresis and visualized by ethidium bromide staining. The genotype $(\mathrm{EE} / \mathrm{EK} / \mathrm{KK})$ frequencies $(\%)$ for the CTRL group (38.2/50.2/11.6), T1D (34.3/52.0/13.7), and T2D (38.2/48.9/12.9) were in Hardy-Weinberg equilibrium and there were no significant differences (CRTL vs T1D, $\mathrm{P}=0.771$; CRTL vs T2D, $\mathrm{P}=$ 0.937 ; T1D vs T2D, $\mathrm{P}=0.831$ ). The minor allele frequencies (MAF; K) for CTRL (37.0\%), T1D (39.7\%), and T2D (37.4\%) were not different among the groups $(\mathrm{P}>0.05)$. The MAF value for healthy subjects was similar to other Caucasian populations (34.5-37.5\%). In summary, the E23K polymorphism (rs5219) was not associated with type 1 or 2 diabetes mellitus in the studied population.

Key words: Diabetes mellitus; Polymorphism; KCNJ11; E23K; Genetic variability; SNP

\section{INTRODUCTION}

Diabetes mellitus (DM) is a disease characterized by chronic hyperglycemia (American Diabetes Association, 2016). DM is a multifactorial disease caused by both genetic and environmental factors and their complex interaction. The two major groups are type 1 diabetes (T1D), an autoimmune disease, and type 2 (T2D), a common form of diabetes associated with insulin resistance. Together these types are responsible for more than $95 \%$ of all patients with diabetes (American Diabetes Association, 2016).

Multiple genes are involved in DM (Basile et al., 2014). Those that have gained the most attention are involved in the insulin secretion pathway (Haghvirdizadeh et al., 2015). Insulin secretion is mediated through ATP-sensitive potassium (KATP) channels in pancreatic $\beta$-cells (Ashcroft and Rorsman, 1989). The KATP channel consists of two types of subunit: an inward-rectifier potassium channel subunit (Kir6.2), and a sulfonylurea receptor (SUR) subunit (Shyng and Nichols, 1997). This channel is a heteromeric protein, composed of four Kir6.2 subunits, forming the pore of the KATP channel, coupled to four high-affinity SUR subunits (Inagaki et al., 1995) surrounding the pore. Kir6.2 is encoded by the potassium inwardly rectifying channel, subfamily J, member 11 (KCNJ11) gene (Basile et al., 2014).

Several single nucleotide polymorphisms (SNPs) have been reported to be associated with susceptibility to different types of DM, including those within the KCNJ11 gene and interacting genes (Gloyn et al., 2003; Haghvirdizadeh et al., 2015). The rs5219 SNP is located in exon 1 of the KCNJ11 gene. A variant of $K C N J 11$, known as E23K, results from a $\mathrm{G} \rightarrow \mathrm{A}$ transition in codon 23 promoting a substitution of glutamine (E) by lysine (K), Lys23Gln, at the $\mathrm{NH}_{2}$-terminal tail of Kir6.2 (Haghvirdizadeh et al., 2015). Association studies of rs5219 have not conclusively connected the polymorphism and susceptibility to T2DM; some studies demonstrated associations (Nielsen et al., 2003; Alsmadi et al., 2008; Tabara et al., 2009; Zhou et al., 2009; Abdelhamid et al., 2014) and others did not confirm this finding (Cauchi et al., 2008; Ezzidi et al., 2009; Nikolac et al., 2009; Neuman et al., 2010; Danquah et al., 2013).

It has been suggested that T1D and T2D may share a degree of common genetic

Genetics and Molecular Research 16 (2): gmr16029543 
predisposition (Wilkin, 2001), given that they both result from abnormal $\beta$-cell function and/or destruction. Therefore, genes involved in insulin secretion and insulin signaling may potentially be risk modifiers for diabetes (Cejková et al., 2007; Ko et al., 2012).

In this study, we examined the association of KCNJ11 polymorphism E23K (rs5219) in Euro-Brazilian individuals with or without T1D or T2D, in a case-control study.

\section{MATERIAL AND METHODS}

\section{Subjects}

The Euro-Brazilian, unrelated subjects $(\mathrm{N}=458)$ in this study were divided into three groups designated as healthy subjects (Control, $\mathrm{N}=217)$, T1D $(\mathrm{N}=102)$, and T2D $(\mathrm{N}=139)$ according to criteria of the American Diabetes Association (2016) and the Brazilian Diabetes Association 2014-2015 (Diretrizes da Sociedade Brasileira de Diabetes, 2014). The healthy subjects recruited were blood donors and patients with diabetes attended in the Clinical Hospital of Universidade Federal do Paraná (HC-UFPR), Curitiba, PR, Brazil. Subjects with overt kidney disease or other severe diabetic complications (myocardial infarction, neuropathy, and retinopathy) were excluded from this study. The Ethics Committee approved this research (registration numbers CEP/SD: 1047.172.10.11 and CEP/HC: 071.EXT.025/2003-02).

\section{Clinical chemistry data and genotyping}

Biochemical parameters were determined using routine laboratory methods (Abbott Diagnostics), including immunoturbidimetry for glycated hemoglobin (HbA1c), conducted with an automated system using reagents, calibrators, and controls provided by the manufacturer (Architect Ci8200, Abbott Diagnostics). The concentration of 1,5-anhydroglucitol (1,5-AG) was measured enzymatically (GlycoMark, Tomen America, New York, NY, USA).

Genomic DNA was extracted from blood samples using the salting-out technique and quantified. The concentration was adjusted to $20 \mathrm{ng} / \mu \mathrm{L}$ with an $\mathrm{A}_{260 / 280}$ ratio of 1.7-1.9.

The E23K of the Kir6.2 polymorphism was genotyped using polymerase chain reaction-restricted fragment length polymorphism (PCR-RFLP) method. The polymorphic site of the Kir6.2 gene was amplified by PCR (forward: 5'-GACTCTGCAGTGAGGCCCTA-3' and reverse: 5'-ACGTTGCAGTTGCCTTTCTT-3' primers) producing an amplicon of $210 \mathrm{bp}$ as described by Nielsen et al. (2003). Briefly, the PCR mix (10 $\mu \mathrm{L}$ volume) contained $100 \mathrm{ng}$ genomic DNA, $5 \mathrm{pmol} / \mathrm{L}$ of each primer, $0.2 \mathrm{mM}$ dNTPs, $1.5 \mathrm{mM}$ magnesium chloride, 0.2 U DNA polymerase (Invitrogen, Waltham, MA, USA), 1X polymerase buffer, and ultrapure water. PCR cycling was 1 cycle at $94^{\circ} \mathrm{C}$ for $3 \mathrm{~min}, 34$ cycles at $94^{\circ} \mathrm{C}$ for $1 \mathrm{~min}, 61.2^{\circ} \mathrm{C}$ for 1 $\mathrm{min}$, and $72^{\circ} \mathrm{C}$ for $1.5 \mathrm{~min}$, and a final step of $72^{\circ} \mathrm{C}$ for $10 \mathrm{~min}$. PCR product $(1 \mu \mathrm{L}, 10-20 \mathrm{ng})$ was digested with $1.0 \mathrm{U}$ BanII enzyme (New England, Ipswich, MA, USA) at $37^{\circ} \mathrm{C}$ overnight. Digested fragments were resolved by $15 \%$ polyacrylamide 29:1 gel electrophoresis (1X TBE buffer) and stained with ethidium bromide.

\section{Statistical analysis}

Normality was verified with the Kolmogorov-Smirnov test. Continuous variables are shown as means \pm standard deviation and the Student $t$-test (two-tailed) was applied in 
comparisons. Non-normally distributed data are shown as median (interquartile range) and compared with the Mann-Whitney U-test.

Discrete variables were compared by the chi-square test. Hardy-Weinberg equilibrium and allele comparisons were calculated with the DeFinetti program (http://ihg.gsf.de/cgi-bin/hw/hwa1.pl).

A probability $(\mathrm{P})$ less than $5 \%(\mathrm{P}<0.05)$ was considered significant in all analyses.

All analyses were performed using the Statistica for Windows 8.0 (StatSoft, Inc., Tulsa, OK, USA) software program.

\section{RESULTS}

On average, healthy subjects (control) were older than T1D patients (33.8 vs 29.7 years, $\mathrm{P}<0.05)$ and much younger than T2D patients $(33.8$ vs 60.4 years, $\mathrm{P}<0.001)$.

Females were predominant in T1D (59.9\%) and T2D (73.3\%), both different $(\mathrm{P}<$ $0.001)$ from the controls, where males were in the majority $(60.8 \%)$.

There was no significant difference between control and T1D body mass index (26.9vs 26.2 $\left.\mathrm{kg} / \mathrm{m}^{2}, \mathrm{P}=0.279\right)$. BMI in T2D $\left(29.8 \mathrm{~kg} / \mathrm{m}^{2}\right)$ was higher than that of the other groups $(\mathrm{P}<0.001)$.

Non-fasting glycemia and HbA1c medians were high $(\mathrm{P}<0.001)$ in T1D $(9.1 \mathrm{mM}$; $9.0 \%)$ and T2D (7.7 mM; 8.5\%) compared with those of the healthy controls $(5.0 \mathrm{mM} ; 5.3 \%)$.

In addition, 1,5-AG concentration was significantly $(\mathrm{P}<0.001)$ reduced in T1D $(20.1$ $\mu \mathrm{M})$ and $\mathrm{T} 2 \mathrm{D}(51.8 \mu \mathrm{M})$ compared with that of the control group $(142.5 \mu \mathrm{M})$.

A significant difference in the concentration of glucose control biomarkers can be observed between the control group and patients with diabetes (Table 1).

Serum creatinine concentration showed no difference among the groups, and urea was significantly higher only in the T2D group. Both of these biomarkers for kidney function were within the reference interval in all groups (Table 1), suggesting no kidney damage.

Total protein and albumin serum concentration were lower $(\mathrm{P}<0.001)$ in T1D and T2D compared to those of the controls.

Table 1. Anthropometric and laboratory characteristics of the studied groups.

\begin{tabular}{|c|c|c|c|c|c|c|}
\hline Parameters & Control $(\mathrm{N}=217)$ & $\mathrm{T} 1 \mathrm{D}(\mathrm{N}=102)$ & T2D $(\mathrm{N}=139)$ & $\mathrm{P}_{\mathrm{CTRL} v s \text { T1D }}$ & $\mathrm{P}_{\mathrm{CTRL} v s \text { T2D }}$ & $\mathrm{P}_{\mathrm{T} 1 \mathrm{D} v s \mathrm{~T} 2 \mathrm{D}}$ \\
\hline Age (years) & $33.8 \pm 11.5$ & $29.7 \pm 13.7$ & $60.4 \pm 10.9$ & 0.005 & $<0.001$ & $<0.001$ \\
\hline Gender (male/female) & $132 / 85$ & $41 / 61$ & $37 / 102$ & $<0.001 * *$ & $<0.001 * *$ & $0.026 * *$ \\
\hline BMI $\left(\mathrm{kg} / \mathrm{m}^{2}\right)$ & $26.9 \pm 5.0$ & $26.2 \pm 6.1$ & $29.8 \pm 6.1$ & 0.279 & $<0.001$ & $<0.001$ \\
\hline Non-fasting glycemia (mM) & $5.0(4.8-5.3)$ & $9.1(5.7-13.6)$ & $7.7(6.1-10.9)$ & $<0.001 *$ & $<0.001 *$ & $0.141 * *$ \\
\hline HbAlc (\%) & $5.3(5.1-5.5)$ & $9.0(7.9-11.1)$ & $7.5(6.4-9.0)$ & $<0.001$ * & $<0.001 *$ & $<0.001$ * \\
\hline $1,5-\mathrm{AG}(\mu \mathrm{M})$ & $142.5(106-179)$ & $20.1(11-40)$ & $51.8(21-95)$ & $<0.001 *$ & $<0.001 *$ & $<0.001 *$ \\
\hline Urea (mM) & $5.1(4.3-5.8)$ & $4.5(3.8-6.5)$ & $5.8(4.6-7.5)$ & $0.715^{*}$ & $<0.001 *$ & $0.004 *$ \\
\hline Creatinine $(\mu \mathrm{M})$ & $74.2(62-79)$ & $70.7(62-79)$ & $70.5(62-88)$ & $0.195^{*}$ & $0.449 *$ & $0.129^{*}$ \\
\hline Total protein $(\mathrm{g} / \mathrm{L})$ & $75(72-79)$ & $71(69-74)$ & $72(69-76)$ & $<0.001 *$ & $<0.001 *$ & $0.080^{*}$ \\
\hline Albumin $(\mathrm{g} / \mathrm{L})$ & $42(41-45)$ & $39(37-41)$ & $39(38-40)$ & $<0.001 *$ & $<0.001 *$ & $0.488^{*}$ \\
\hline
\end{tabular}

Values are reported as means \pm standard deviation, median (interquartile range), or number (N) of individuals. Control, healthy subjects; T1D, type 1 diabetes, T2D, type 2 diabetes; 1,5-AG, 1,5-anhydroglucitol; HbA1c, glycated hemoglobin A1c; BMI, body mass index. Probability (P), Student- $t$ test (two-tailed), *Mann-Whitney U-test or **chi-square test. Significant $\mathrm{P}$ values $(\mathrm{P}<0.05)$ are in bold.

The genotype distributions in all groups were in Hardy-Weinberg equilibrium (Table 2).

The genotype frequencies of E23K (rs5219) showed no difference among the studied groups $(\mathrm{P}>0.05)$, either in dominant or recessive models. The minor allele frequencies (MAF), A-allele (K-allele), were not different among the groups $(\mathrm{P}>0.05)$.

Genetics and Molecular Research 16 (2): gmr16029543 
In addition, anthropometric (BMI) and biochemical parameters (non-fasting glycemia, $\mathrm{HbAlc}$, 1,5-AG, urea, and creatinine) did not show association with the E23K genotypes (data not shown).

Table 2. Genotypes and allele frequencies for the polymorphism E23K (rs5219) in the studied groups.

\begin{tabular}{|c|c|c|c|c|c|c|}
\hline Genotypes (allele) & Control $(\mathrm{N}=217)$ & $\mathrm{T} 1 \mathrm{D}(\mathrm{N}=102)$ & T2D $(\mathrm{N}=139)$ & P Control $v s$ T1D & P Control vs T2D & $\mathrm{P}$ T1D $v s$ T2D \\
\hline rs5219(E23K) & & & & \multirow[t]{4}{*}{0.771} & \multirow[t]{4}{*}{0.937} & \multirow[t]{4}{*}{0.831} \\
\hline $\mathrm{G} / \mathrm{G}(\mathrm{EE})$ & $83(38.2)$ & $35(34.3)$ & $53(38.2)$ & & & \\
\hline G/A (EK) & $109(50.2)$ & $53(52.0)$ & $68(48.9)$ & & & \\
\hline $\mathrm{A} / \mathrm{A}(\mathrm{KK})$ & 25 (11.6) & $14(13.7)$ & $18(12.9)$ & & & \\
\hline A-allele $(95 \% \mathrm{CI})$ & $37.0(33-42)]$ & $39.7(33-46)$ & $37.4(32-43)$ & 0.489 & 0.881 & 0.608 \\
\hline GG $v s \mathrm{GA}+\mathrm{AA}^{*}$ & 83 vs 134 & 35 vs 67 & 53 vs 86 & 0.497 & 0.982 & 0.543 \\
\hline AA $v s$ GG $+\mathrm{GA}^{* *}$ & 25 vs 192 & 14 vs 88 & 18 vs 121 & 0.575 & 0.686 & 0.861 \\
\hline
\end{tabular}

Values are reported as $\mathrm{N}(\%)$. E23K, substitution of a lysine (K) at position 23 for glutamic acid (E). Probability (P), chi-square test; 95\% CI, confidence interval of 95\%. All groups were in Hardy-Weinberg equilibrium (Control, $\mathrm{P}=0.227 ; \mathrm{T} 1 \mathrm{D}, \mathrm{P}=0.389$, and T2D, $\mathrm{P}=0.598)$. ${ }^{*}$ Dominant model and $* *$ Recessive model.

Genotypes and allele frequencies observed for E23K were compared with other studies and populations (Table 3). Similarities with our study were considered when the MAF were within the $95 \%$ confidence interval.

Table 3. Genotype and allele frequencies of the KCNJ11 rs5219 polymorphism from a literature review.

\begin{tabular}{|c|c|c|c|c|c|c|c|}
\hline \multicolumn{3}{|l|}{$K C N J 11$ rs5219 } & \multicolumn{3}{|c|}{ Genotype (\%) } & \multirow{2}{*}{$\begin{array}{c}\text { Allele (\%) } \\
\text { A } \\
\end{array}$} & \multirow[t]{2}{*}{ References } \\
\hline Ethnic groups & Characteristics & $\mathrm{N}$ & GG & GA & AA & & \\
\hline \multirow[t]{3}{*}{ Euro- Brazilian } & Healthy (control) & 220 & 38.2 & 50.2 & 11.6 & $37.0(33-42)$ & \multirow[t]{3}{*}{ Present study } \\
\hline & T1D & 101 & 34.3 & 52.0 & 13.7 & $39.7(33-46)$ & \\
\hline & T2D & 139 & 38.2 & 48.9 & 12.9 & $37.4(32-43)$ & \\
\hline \multirow{2}{*}{ Chinese Han } & Healthy & 1910 & 36.2 & 48.7 & 15.1 & 39.4 & \multirow{2}{*}{ Zhou et al., 2009} \\
\hline & T2D & 1848 & 35.5 & 46.7 & 17.8 & 41.2 & \\
\hline \multirow[t]{2}{*}{ Mauritanian } & Healthy & 135 & 73.3 & 22.2 & 4.5 & 16 & \multirow[t]{2}{*}{ Abdelhamid et al., 2014} \\
\hline & T2D & 135 & 63.7 & 28.9 & 7.4 & 22 & \\
\hline \multirow[t]{2}{*}{ Japanese } & Healthy & 397 & 38.3 & 49.1 & 12.6 & 37.2 & \multirow[t]{2}{*}{ Tabara et al., 2009} \\
\hline & T2D & 484 & 34.9 & 47.9 & 17.2 & 41.1 & \\
\hline \multirow[t]{2}{*}{ Arabs } & Healthy & 335 & 75.2 & 22.4 & 2.4 & 13.6 & \multirow[t]{2}{*}{ Alsmadi et al., 2008} \\
\hline & $\mathrm{T} 2 \mathrm{D}$ & 550 & 62.0 & 34 & 4 & 21 & \\
\hline \multirow[t]{2}{*}{ UK } & Healthy & 307 & 41.0 & 49.0 & 10.0 & 34.5 & \multirow[t]{8}{*}{ Nielsen et al., 2003} \\
\hline & T2D & 360 & 37.0 & 45.0 & 18.0 & 40.6 & \\
\hline \multirow[t]{2}{*}{ France } & Healthy & 114 & 40.0 & 46.0 & 14.0 & 36.8 & \\
\hline & T2D & 191 & 28.0 & 45.0 & 27.0 & 49.7 & \\
\hline \multirow{2}{*}{ Utah } & Healthy & 68 & 31.0 & 65.0 & 4.0 & 36.8 & \\
\hline & T2D & 119 & 44.0 & 46.0 & 10.0 & 33.2 & \\
\hline \multirow[t]{2}{*}{ Danish } & Healthy & 862 & 39.0 & 47.0 & 14.0 & 37.5 & \\
\hline & T2D & 803 & 36.0 & 47.0 & 17.0 & 40.5 & \\
\hline \multirow[t]{2}{*}{ African } & Healthy & 377 & 0 & 0 & 100 & 100 & \multirow[t]{2}{*}{ Danquah et al., 2013} \\
\hline & T2D & 675 & 0 & 0.1 & 99.9 & 100 & \\
\hline Croatian & T2D on sulfonylurea therapy & 228 & 38.3 & 45.2 & 16.7 & 39.3 & Nikolac et al., 2009 \\
\hline \multirow[t]{2}{*}{ Tunisian } & Healthy & 503 & 49.7 & 42.3 & 8.0 & 29 & \multirow[t]{2}{*}{ Ezzidi et al., 2009} \\
\hline & T2D & 805 & 46.1 & 43.7 & 10.2 & 32 & \\
\hline \multirow[t]{4}{*}{ Caucasian } & Healthy non-obese & 3022 & 38 & 48 & 15 & 38.3 & \multirow[t]{4}{*}{ Cauchi et al., 2008} \\
\hline & T2D non-obese & 1206 & 41 & 45 & 15 & 37.2 & \\
\hline & Healthy obese & 1212 & 40 & 47 & 14 & 37.0 & \\
\hline & T2D obese & 1528 & 41 & 45 & 15 & 36.9 & \\
\hline \multirow[t]{2}{*}{ Ashkenazi Jewish } & Healthy & 743 & 40.2 & 47.9 & 11.7 & 35.7 & Neuman et al., 2010 \\
\hline & T2D & 573 & 39.8 & 46.4 & 13.8 & 37.0 & \\
\hline Korean & Healthy & 630 & 40.5 & 43.3 & 16.2 & 37.9 & Ko et al., 2012 \\
\hline & T1D & 70 & 30.0 & 44.3 & 25.7 & 47.9 & \\
\hline Czech & Healthy & 113 & 42.5 & 41.6 & 15.9 & 36.7 & Cejková et al., 2007 \\
\hline & T1D & 16 & 31.2 & 43.8 & 25.0 & 49.6 & \\
\hline & T2D & 172 & 38.4 & 49.4 & 12.2 & 36.9 & \\
\hline & LADA & 44 & 50.0 & 41.7 & 8.3 & 29.3 & \\
\hline
\end{tabular}

Bold values indicate data obtained in this study; bold and italic values represent MAF (A-allele) outside of the $95 \%$ confidence interval. Values are reported as percentage or range and $95 \%$ confidence interval. T1D: type 1 diabetes; T2D: type 2 diabetes; LADA: latent autoimmune diabetes in adults.

Genetics and Molecular Research 16 (2): gmr16029543 


\section{DISCUSSION}

The high concentration of HbA1c in T1D compared to T2D (9.0 vs 7.5\%, $\mathrm{P}<0.001$; Table 1) may be associated with poor glycemic control, a common finding in insulin users. In agreement with these findings, further studies have shown that 1,5-AG concentrations are consistently and markedly decreased in T1D (mean 21 to $95 \mu \mathrm{M}$ ) (Yamanouchi et al., 1992) when compared to T2D patients (mean values of 31.6 to $74.3 \mu \mathrm{M}$ ) (Yamanouchi et al., 1992), and in this study (T1D 20.1 $\mu \mathrm{M}$ and T2D $51.8 \mu \mathrm{M}$ ). The 1,5-AG plasma concentration difference between T1D and T2D in this study was significant $(\mathrm{P}<0.001)$ and also consistent with that reported by Yamanouchi et al. (1992).

Concentrations of $\mathrm{HbA} 1 \mathrm{c}>7.0 \%(>53 \mathrm{mmol} / \mathrm{mol})$ and $1,5-\mathrm{AG}<61 \mu \mathrm{M}(<10 \mathrm{mg} / \mathrm{mL})$, a marker for hyperglycemic excursions, suggested poor glycemic control. These characteristics were observed in our diabetes groups T1D and T2D (Table 1).

Although the T2D group had urea concentration higher than that of the control and T1D groups (Table 1), it is not outside the reference range $(2.5-7.5 \mathrm{mM})$, indicating that the diabetes groups did not show an overt nephropathy. Hyperglycemia leads to hyperfiltration early in the course of diabetes, and hence increased glomerular filtration rate (Jerums et al., 2010). This increased glomerular filtration rate could result in lower creatinine levels in patients with diabetes compared to the control group. The higher urea level in T2D could be a result of lower urea excretion in attempting to produce more concentrated urine (Bankir et al., 1993). This profile of renal function markers, higher urea, and lower creatinine levels in T2D compared to controls was similar to that found by Kornhauser et al. (2008).

Patients with T1D and T2D are subject to inflammatory processes and microalbuminuria, and both conditions can reduce plasma albumin concentrations (Jerums et al., 2010). These characteristics could partially explain the small reduction in protein concentration in the diabetes groups. In addition, increases in glomerular filtration rate and subtle increases in urinary albumin excretion have been reported early in the course of diabetes (Jerums et al., 2010).

Susceptibility genes associated with T1D and T2D have generally not been shown to overlap (Basile et al., 2014). A few studies have been carried out to evaluate the effects on the risk of T1D (Cejková et al., 2007; Qu et al., 2008; Raj et al., 2009; Ko et al., 2012) and none of them has observed association in Caucasians and Asians. The allele frequency for rs5219 reported in the present study was slightly lower than the rate reported for Korean (Cejková et al., 2007) and Czech (Ko et al., 2012) populations (Table 3), but similar to Caucasian populations (36\%) (Raj et al., 2009).

Despite some reports, which found an association between the E23K polymorphism of Kir6.2 and the development of T2D (Nielsen et al., 2003; Alsmadi et al., 2008; Tabara et al., 2009; Zhou et al., 2009; Abdelhamid et al., 2014), our results showed no association, which was in agreement with other studies (Inoue et al., 1997; Yokoi et al., 2006; Cejková et al., 2007; Cauchi et al., 2008; Keshavarz et al., 2014). The MAF (A-allele) in our study of EuroBrazilians overlaps the $95 \%$ confidence interval for several European populations (Table 3), suggesting consistency.

A meta-analysis for European populations confirmed the association between the E23K polymorphism and susceptibility to T2D in a large cohort (Gloyn et al., 2003). The cohort studied was enriched for familiarity, and the authors suggested that to assess the trueattributable risk of this variant, cohorts of random type 2 diabetes populations are needed (Gloyn et al., 2003).

Genetics and Molecular Research 16 (2): gmr16029543 
Although there is general agreement that this polymorphism is a risk factor for T2D in several populations, the data are still inconsistent (Inoue et al., 1997; Gloyn et al., 2003; Nielsen et al., 2003; Yokoi et al., 2006; Wang et al., 2009). Hirschhorn and Altshuler (2002) suggest some reasons for failures to replicate associations between genetic variants and T2D. Among them, studies underpowered to detect the modest impact of individual loci or etiologic heterogeneity across populations are proposed.

E23K is a common polymorphism worldwide and each copy of the susceptibility allele has a modest effect (odds ratio 1.15) on T2D (Zhou et al., 2009), but due to its high allele frequency, it is likely to have a large effect on population attributable risk (Gloyn et al., 2003). Therefore, the small sample size of our study could be a limitation of the statistical power of the test. Nevertheless, a study by Cauchi et al. (2008) conducted with sufficient statistical power did not support a role for E23K as a T2D risk factor. Furthermore, it has been reported that the E23K variant is in strong linkage disequilibrium with rs 1799854 located on the $A B C C 8$ gene (Tabara et al., 2009). In all examined populations, lysine carriers at KCNJ11 E23K almost invariably carry the alanine allele at $A B C C 8$ rs 757110 (A1369S), and it remains possible that either or both variants are actually required to produce these effects. However, in this study, we did not consider the effect of $A B C C 8$ variants on promoting T2D.

Genetic background can affect susceptibility to T2D (Haghvirdizadeh et al., 2015) and miscegenation in Brazil is very high. Sale et al. (2007) found borderline association with KCNJ11 $\mathrm{E} 23 \mathrm{~K}(\mathrm{P}=0.044)$; however, after adjustment for admixture the association became insignificant.

In addition, environmental elements, such as BMI and physical activity, are involved in the etiology of T2D and have higher predictive power when compared to genetic information (Sargeant et al., 2000). Therefore, obesity may influence the contribution of genetic factors such as E23K on T2D development in different populations. Indeed, associations have been shown between the E23K variant and a significant increase in BMI (Nielsen et al., 2003), and with T2D in the presence of obesity (Keshavarz et al., 2014). It has been shown that a polymorphism (R1273R) in the $A B C C 8$ gene is significantly associated with progression of T2D in obese individuals (Evliyaoglu et al., 2011). This association information shows strong linkage disequilibrium between polymorphisms present in $K C N J 11$ and $A B C C 8$ genes, and could suggest that mutation in both $K C N J 11$ and $A B C C 8$ variants is required to cause the development of T2D in obese subjects. However, Cauchi et al. (2008) did not observe this effect. Contrary to this hypothesis, all variants, which have been associated with insulin secretion (Holmkvist et al., 2006; Steinthorsdottir et al., 2007; Terauchi et al., 2007), were only associated with T2D in non-obese patients.

Therefore, genetic studies of this and other polymorphisms in and associated with the KCNJ11 gene are needed, not only for replication of these findings, but also for assessing its effect on T2D pathogenesis in populations with different genetic backgrounds and environments.

Our study shows similar results to those of European population-based studies presented in Table 3, indicating the consistency of our findings.

In summary, our study found no evidence to suggest that the KCNJ11 polymorphism E23K (rs5219) plays a key role as a risk factor for T1D or T2D in the Euro-Brazilian population.

\section{ACKNOWLEDGMENTS}

Research supported by CNPq (Conselho Nacional de Desenvolvimento Científico e Tecnológico) and Fundação Araucária.

Genetics and Molecular Research 16 (2): gmr16029543 


\section{REFERENCES}

Abdelhamid I, Lasram K, Meiloud G, Ben Halim N, et al. (2014). E23K variant in KCNJ11 gene is associated with susceptibility to type 2 diabetes in the Mauritanian population. Prim. Care Diabetes 8: 171-175. http://dx.doi. org/10.1016/j.pcd.2013.10.006

Alsmadi O, Al-Rubeaan K, Wakil SM, Imtiaz F, et al. (2008). Genetic study of Saudi diabetes (GSSD): significant association of the KCNJ11 E23K polymorphism with type 2 diabetes. Diabetes Metab. Res. Rev. 24: 137-140. http:// dx.doi.org/10.1002/dmrr.777

American Diabetes Association (2016). Standards of Medical Care in Diabetes-2016 Abridged for Primary Care Providers. Clin. Diabetes 34: 3-21. http://dx.doi.org/10.2337/diaclin.34.1.3

Ashcroft FM and Rorsman P (1989). Electrophysiology of the pancreatic beta-cell. Prog. Biophys. Mol. Biol. 54: 87-143. http://dx.doi.org/10.1016/0079-6107(89)90013-8

Bankir L, Ahloulay M, Bouby N, Trinh-Trang-Tan MM, et al. (1993). Is the process of urinary urea concentration responsible for a high glomerular filtration rate? J. Am. Soc. Nephrol. 4: 1091-1103.

Basile KJ, Guy VC, Schwartz S and Grant SF (2014). Overlap of genetic susceptibility to type 1 diabetes, type 2 diabetes, and latent autoimmune diabetes in adults. Curr. Diab. Rep. 14: 550. http://dx.doi.org/10.1007/s11892-014-0550-9

Cauchi S, Nead KT, Choquet H, Horber F, et al. (2008). The genetic susceptibility to type 2 diabetes may be modulated by obesity status: implications for association studies. BMC Med. Genet. 9: 45. http://dx.doi.org/10.1186/1471-2350$\underline{9-45}$

Cejková P, Novota P, Cerná M, Kolostová K, et al. (2007). KCNJ11 E23K polymorphism and diabetes mellitus with adult onset in Czech patients. Folia Biol. (Praha) 53: 173-175.

Danquah I, Othmer T, Frank LK, Bedu-Addo G, et al. (2013). The TCF7L2 rs7903146 (T) allele is associated with type 2 diabetes in urban Ghana: a hospital-based case-control study. BMC Med. Genet. 14: 96. http://dx.doi. org/10.1186/1471-2350-14-96

Diretrizes da Sociedade Brasileira de Diabetes (2014). 2013-2014/Sociedade Brasileira de Diabetes. AC Farmacêutica, São Paulo.

Evliyaoglu O, Sancaktar E, Söğüt E, Başaralı M, et al. (2011). Association of a single nucleotide polymorphism in the SUR1 gene with type 2 diabetes and obesity in Turkish patients. J. Clin. Exp. Invest. 2: 7. http://dx.doi.org/10.5799/ ahinjs.01.2011.02.0232

Ezzidi I, Mtiraoui N, Cauchi S, Vaillant E, et al. (2009). Contribution of type 2 diabetes associated loci in the Arabic population from Tunisia: a case-control study. BMC Med. Genet. 10: 33. http://dx.doi.org/10.1186/1471-2350-10-33

Gloyn AL, Weedon MN, Owen KR, Turner MJ, et al. (2003). Large-scale association studies of variants in genes encoding the pancreatic beta-cell KATP channel subunits Kir6.2 (KCNJ11) and SUR1 (ABCC8) confirm that the KCNJ11 E23K variant is associated with type 2 diabetes. Diabetes 52: 568-572. http://dx.doi.org/10.2337/diabetes.52.2.568

Haghvirdizadeh P, Mohamed Z, Abdullah NA, Haghvirdizadeh P, et al. (2015). KCNJ11: Genetic Polymorphisms and Risk of Diabetes Mellitus. J. Diabetes Res. 2015: 908152. http://dx.doi.org/10.1155/2015/908152

Hirschhorn JN and Altshuler D (2002). Once and again-issues surrounding replication in genetic association studies. $J$. Clin. Endocrinol. Metab. 87: 4438-4441. http://dx.doi.org/10.1210/jc.2002-021329

Holmkvist J, Cervin C, Lyssenko V, Winckler W, et al. (2006). Common variants in HNF-1 alpha and risk of type 2 diabetes. Diabetologia 49: 2882-2891. http://dx.doi.org/10.1007/s00125-006-0450-x

Inagaki N, Gonoi T, Clement JPT, 4th, Namba N, et al. (1995). Reconstitution of IKATP: an inward rectifier subunit plus the sulfonylurea receptor. Science 270: 1166-1170. http://dx.doi.org/10.1126/science.270.5239.1166

Inoue H, Ferrer J, Warren-Perry M, Zhang Y, et al. (1997). Sequence variants in the pancreatic islet beta-cell inwardly rectifying $\mathrm{K}^{+}$channel Kir6.2 (Bir) gene: identification and lack of role in Caucasian patients with NIDDM. Diabetes 46: 502-507. http://dx.doi.org/10.2337/diab.46.3.502

Jerums G, Premaratne E, Panagiotopoulos S and MacIsaac RJ (2010). The clinical significance of hyperfiltration in diabetes. Diabetologia 53: 2093-2104. http://dx.doi.org/10.1007/s00125-010-1794-9

Keshavarz P, Habibipour R, Ghasemi M, Kazemnezhad E, et al. (2014). Lack of genetic susceptibility of KCNJ11 E23K polymorphism with risk of type 2 diabetes in an Iranian population. Endocr. Res. 39: 120-125. http://dx.doi.org/10. 3109/07435800.2013.860607

Ko JM, Yang S, Kim SY, Lee HS, et al. (2012). E23K polymorphism of the KCNJ11 gene in Korean children with type 1 diabetes. World J. Pediatr. 8: 169-172. http://dx.doi.org/10.1007/s12519-012-0355-3

Kornhauser C, Garcia-Ramirez JR, Wrobel K, Pérez-Luque EL, et al. (2008). Serum selenium and glutathione peroxidase concentrations in type 2 diabetes mellitus patients. Prim. Care Diabetes 2: 81-85. http://dx.doi.org/10.1016/j. pcd.2008.02.003

Genetics and Molecular Research 16 (2): gmr16029543 
Neuman RJ, Wasson J, Atzmon G, Wainstein J, et al. (2010). Gene-gene interactions lead to higher risk for development of type 2 diabetes in an Ashkenazi Jewish population. PLoS One 5: e9903. http://dx.doi.org/10.1371/journal. pone.0009903

Nielsen EM, Hansen L, Carstensen B, Echwald SM, et al. (2003). The E23K variant of Kir6.2 associates with impaired post-OGTT serum insulin response and increased risk of type 2 diabetes. Diabetes 52: 573-577. http://dx.doi. org/10.2337/diabetes.52.2.573

Nikolac N, Simundic AM, Katalinic D, Topic E, et al. (2009). Metabolic control in type 2 diabetes is associated with sulfonylurea receptor-1 (SUR-1) but not with KCNJ11 polymorphisms. Arch. Med. Res. 40: 387-392. http://dx.doi. org/10.1016/j.arcmed.2009.06.006

Qu HQ, Grant SF, Bradfield JP, Kim C, et al. (2008). Association analysis of type 2 diabetes Loci in type 1 diabetes. Diabetes 57: 1983-1986. http://dx.doi.org/10.2337/db08-0270

Raj SM, Howson JM, Walker NM, Cooper JD, et al. (2009). No association of multiple type 2 diabetes loci with type 1 diabetes. Diabetologia 52: 2109-2116. http://dx.doi.org/10.1007/s00125-009-1391-y

Sale MM, Smith SG, Mychaleckyj JC, Keene KL, et al. (2007). Variants of the transcription factor 7-like 2 (TCF7L2) gene are associated with type 2 diabetes in an African-American population enriched for nephropathy. Diabetes 56 : 2638-2642. http://dx.doi.org/10.2337/db07-0012

Sargeant LA, Wareham NJ and Khaw KT (2000). Family history of diabetes identifies a group at increased risk for the metabolic consequences of obesity and physical inactivity in EPIC-Norfolk: a population-based study. The European Prospective Investigation into Cancer. Int. J. Obes. Relat. Metab. Disord. 24: 1333-1339. http://dx.doi.org/10.1038/ sj.ijo.0801383

Shyng S and Nichols CG (1997). Octameric stoichiometry of the KATP channel complex. J. Gen. Physiol. 110: 655-664. http://dx.doi.org/10.1085/jgp.110.6.655

Steinthorsdottir V, Thorleifsson G, Reynisdottir I, Benediktsson R, et al. (2007). A variant in CDKAL1 influences insulin response and risk of type 2 diabetes. Nat. Genet. 39: 770-775. http://dx.doi.org/10.1038/ng2043

Tabara Y, Osawa H, Kawamoto R, Onuma H, et al. (2009). Replication study of candidate genes associated with type 2 diabetes based on genome-wide screening. Diabetes 58: 493-498. http://dx.doi.org/10.2337/db07-1785

Terauchi Y, Takamoto I, Kubota N, Matsui J, et al. (2007). Glucokinase and IRS-2 are required for compensatory beta cell hyperplasia in response to high-fat diet-induced insulin resistance. J. Clin. Invest. 117: 246-257. http://dx.doi. org/10.1172/JCI17645

Wang F, Han XY, Ren Q, Zhang XY, et al. (2009). Effect of genetic variants in KCNJ11, ABCC8, PPARG and HNF4A loci on the susceptibility of type 2 diabetes in Chinese Han population. Chin. Med. J. (Engl.) 122: 2477-2482.

Wilkin TJ (2001). The accelerator hypothesis: weight gain as the missing link between Type I and Type II diabetes. Diabetologia 44: 914-922. http://dx.doi.org/10.1007/s001250100548

Yamanouchi T, Moromizato H, Shinohara T, Minoda S, et al. (1992). Estimation of plasma glucose fluctuation with a combination test of hemoglobin A1c and 1,5-anhydroglucitol. Metabolism 41: 862-867. http://dx.doi. org/10.1016/0026-0495(92)90168-A

Yokoi N, Kanamori M, Horikawa Y, Takeda J, et al. (2006). Association studies of variants in the genes involved in pancreatic beta-cell function in type 2 diabetes in Japanese subjects. Diabetes 55: 2379-2386. http://dx.doi. org/10.2337/db05-1203

Zhou D, Zhang D, Liu Y, Zhao T, et al. (2009). The E23K variation in the KCNJ11 gene is associated with type 2 diabetes in Chinese and East Asian population. J. Hum. Genet. 54: 433-435. http://dx.doi.org/10.1038/jhg.2009.54

Genetics and Molecular Research 16 (2): gmr16029543 